\title{
PENGARUH SISTEM AKUNTANSI MANAJEMEN DAN KETIDAKPASTIAN LINGKUNGAN TERHADAP KINERJA MANAJERIAL PADA PT. ADIRA DINAMIKA MULTI FINANCE TBK KANTOR CABANG JAYAPURA
}

\author{
Nurul Ilmy M \\ Universitas Muslim Indonesia Makassar \\ Email: rulilmy22@icloud.com \\ Abdul Rahman Mus \\ Universitas Muslim Indonesia Makassar \\ Email: abdulrahmanmus@umi.ac.id \\ Hamzah Ahmad \\ Universitas Muslim Indonesia Makassar \\ Email: hamzahahmad@umi.ac.id
}

\begin{abstract}
author has the objective to determine the effect of management accounting system and environmental uncertainty on managerial performance on PT Adira Dinamika Multifinance Tbk Branch Office Jayapura. The hypothesis of this study is: Suspected of management accounting system and environmental uncertainty have a significant impact on the performance of managerial on On Adira Dinamika Multifinance Tbk Branch Office Jayapura. The data required in this study is primary data in the form of respondents' assessment of management accounting system, environmental uncertainty and performance of managerial. Data collection methods used in this study is the questionnaire as well as a literature review on the books related to the subject matter covered. Data analysis techniques used by Multiple Linear Regression Test, $t$ test, $F$ test, Coefficient of Determination Test. The results of this study indicate: (1) management accounting system a positively and significantly effect on the managerial performance; and (2) environmental uncertainty a positively and significantly effect on the managerial performance.
\end{abstract}

Keyword: Management Accounting System, Environmental Uncertainty and Managerial Performance

\begin{abstract}
Abstrak
Penelitian ini bertujuan untuk mengetahui pengaruh sistem akuntansi manajemen dan ketidakpastian lingkungan terhadap kinerja manajerial pada PT Adira Dinamika Multifinance Tbk Kantor Cabang Jayapura. Hipotesis penelitian ini adalah sistem akuntansi manajemen dan ketidakpastian lingkungan berpengaruh signifikan terhadap kinerja manajerial pada PT Adira Dinamika Multifinance Tbk Kantor Cabang Jayapura. Data yang digunakan dalam penelitian ini adalah data primer dalam bentuk penilaian responden tentang sistem akuntansi manajemen, ketidakpastian lingkungan dan kinerja manajerial. Metode pengumpulan data menggunakan kuisioner dan studi Pustaka. Teknik analisis data menggunakan analisis regresi linear berganda, uji t, uji F dan uji koefisinen determinasi. Hasil penelitian menunjukkan bahwa: (1) sistem akuntansi manajemen berpengaruh positif dan signifikan terhadap kinerja manajerial; dan (2) ketidakpastian lingkungan berpengaruh positif dan signifikan terhadap kinerja manajerial.
\end{abstract}

Kata kunci: Sistem Akuntansi Manajemen, ketidakpastian lingkungan dan Kinerja Manajerial 


\section{PENDAHULUAN}

Kinerja perusahaan sebagian besar dipengaruhi oleh kinerja manajerialnya. Tanpa mengenyampingkan kinerja operasional suatu organisasi, keberhasilan suatu organisasi dalam mencapai tujuannya sebagian besar tergantung pada kinerja manajerialnya. Kinerja manajerial dapat dijelaskan sebagai eksistensi kerja manajer (pimpinan) dalam menyelesaikan pekerjaan dengan seefektif mungkin (Soobaroyen dan Poorundersing dalam Rante, dkk, 2014).

Kinerja manajerial merupakan hasil kerja secara kualitas dan kuantitas yang dicapai oleh seseorang manajer dalam melaksanakan tugasnya sesuai dengan tanggung jawab yang diberikan kepadanya (Ingkiriwang, 2013). Ayu dan Dahen (2014) berpendapat bahwa kinerja manajerial merupakan hasil dan keluaran yang dihasilkan oleh manajer sesuai dengan perannya dalam organisasi dalam suatu periode tertentu. Pada umumnya keberhasilan suatu perusahaan banyak tergantung pada faktor - faktor manajerial.

Ada banyak faktor yang memengaruhi kinerja manajerial, dua di antaranya adalah sistem akuntansi manajemen dan ketidakpastian lingkungan. Sistem akuntansi manajemen menurut Hansen dan Mowen (2009) dalam Qibtiyah (2018), adalah proses yang digambarkan oleh aktivitas aktivitas seperti pengumpulan, mengukur, mengarsipkan, menganalisis, pelaporan untuk pengelolaan suatu informasi.

Mia dan Chanel dalam Sianipar (2018), mengemukakan bahwa jika para manajer menggunakan informasi yang disediakan oleh sistem akuntansi manajemen maka para manajer tersebut dapat melaksanakan hal yang lebih baik dalam melaksanakan pekerjaan dan perbaikan dalam kinerjanya. Penggunaan sistem akuntansi manajemen perusahaan akan mendapat informasi-informasi yang sangat penting.

Sistem akuntansi manajemen juga dapat memuat informasi - informasi yang dapat dijadikan sebagai dasar untuk program promosi, untuk penjualan, untuk pajak, kategori pelanggan dan tingkat pelanggan. Hal tersebut juga dapat dijadikan sebagai salah satu rencana sarana untuk lebih meningkatkan pelayanan dan kualitas perusahaan itu sendiri. Selanjutnya para manajer yang dapat menggunakan sistem akuntansi manajemen dengan baik, sangat memungkinkan para manajer tersebut untuk melihat dan memastikan apakah perusahaan mereka bersaing dengan perusahaan-perusahaan pesaing mereka, dalam penawaran produk dan pelayanan untuk konsumen berupa harga yang kompetitif, pelayanan dan fasilitas yang mereka punya untuk konsumen.

Hasil penelitian Wulandari, dkk (2014), Lempas,dkk (2014), Rante, dkk (2014), dan Damayanti, dkk (2015), menyatakan bahwa sistem akuntansi manajemen berpengaruh positif dan signifikan terhadap kinerja manajerial. Sedangkan Hasil penelitian Qibtiyah (2018), menemukan bahwa sistem akuntansi manajemen berpengaruh negatif terhadap kinerja manajerial. Sementara hasil penelitian Ingkiriwang (2013), menemukan bahwa Sistem Akuntansi Manajemen tidak berpengaruh signifikan terhadap kinerja manajer.

Selain sistem akuntansi manajemen, faktor lain yang berhubungan dengan kinerja manajerial adalah ketidakpastian lingkungan. Ketidakpastian merupakan suatu faktor 
dari situasi yang dihadapi oleh sebagian besar manajer pada organisasi yang sulit untuk diperkirakan. Akibat yang ditimbulkan dari ketidakpastian adalah hasil dari keputusan yang telah dibuat mungkin akan berbeda dari apa yang telah diperkirakan saat pengambilan keputusan. Menurut Akhmad dan Jauhar (2013) ketidakpastian lingkungan adalah suatu keadaan dimana organisasi atau pimpinannya tidak mempunyai informasi yang cukup mengenai keadaan lingkungannya, sehingga akan menyebabkan timbulnya kesulitan dalam memperkirakan perubahan-perubahan lingkungan yang akan terjadi. Kondisi ketidakpastian lingkungan dan persaingan yang sangat ketat dapat menjadikan informasi sebagai komoditas yang berguna bagi perusahaan dalam kegiatan perencanaan, pengendalian serta pembuatan keputusan.

$$
\text { Hasil penelitian Damayanti }
$$

(2015) dan Prihatningtyas (2018), menemukan bahwa ketidakpasitan lingkungan berpangaruh terhadap kinerja manajerial. Sementara hasil penelitian Anita (2017), menemukan bahwa ketidakpasitan lingkungan tidak berpangaruh terhadap kinerja manajerial.

Berdasarkan hasil review penelitian terdahulu di atas didapatkan research gap berupa inkonsisten (tidak konsisten) hasil penelitian. Dengan kata lain, tidak selalu kinerja manajerial dipengaruhi oleh sistem akuntansi manajemen dan ketidakpastian lingkungan. Oleh karenanya peneliti tertarik untuk kembali menguji pengaruh sistem akuntansi manajemen dan ketidakpastian lingkungan terhadap kinerja manajerial dengan mengambil PT. Adira Dinamika Multi Finance, Tbk Kantor Cabang Jayapura sebagai lokasi penelitian.

PT. Adira Dinamika Multi Finance, Tbk Cabang Jayapura merupakan sebuah perusahaan jasa keuangan yang sedang berkembang sehingga memerlukan Langkah - langkah guna meningkatkan kepuasan nasabahnya dengan menjalankan usaha penjualan secara angsuran kepada para konsumen bermotor untuk semua merek. Pada awalnya PT Adira Dinamika Multi Finance Tbk Cabang Jayapura hanya menyediakan produk kendaraan roda dua yang kemudian bertambah dengan produk elektronik dan lainnya.

Banyaknya perusahaan sejenis yang bergerak dalam bidang jasa pembiayaan telah memberi dampak pada semakin ketatnya persaingan, sehingga dapat mempengaruhi pasar sasaran walaupun Adira Finance telah memiliki lisensi dari setiap pengajuan kredit pembiayaan kendaraan roda dua. Keadaan ini berpengaruh terhadap fluktuasi volume penjualan sehingga memaksa jajaran manajerialnya bekerja dengan baik. Persaingan yang semakin ketat menuntut perusahaan untuk menciptakan nilai dan daya saing dari aspek yang berbeda. Sehingga sudah saatnya bagi perusahaan untuk menempatkan SDM sebagai aset strategis dan menentukan strategi yang tepat dengan menyusun rencana kerja, pengelolaan dan operasional bisnis yang harus dijalankan SDM ditunjang dengan sistem yang sudah diterapkan. 
Tabel 1

Hasil Penilaian Kinerja Manajerial

PT. Adira Dinamika Multi Finance, Tbk

Kantor Cabang Jayapura 2017 - 2019

\begin{tabular}{|c|l|c|c|c|}
\hline \multirow{2}{*}{ No } & \multicolumn{1}{|c|}{ Indikator } & \multicolumn{3}{|c|}{ Tahun } \\
\cline { 3 - 5 } & & $\begin{array}{c}\mathbf{2 0 1 7} \\
(\%)\end{array}$ & $\begin{array}{c}\mathbf{2 0 1 8} \\
\mathbf{( \% )}\end{array}$ & $\begin{array}{c}\mathbf{2 0 1 9} \\
\text { (\%) }\end{array}$ \\
\hline 1. & Jumlah pembiayaan yang dapat dipenuhi sesuai skedul & 14,23 & 9,00 & 10,23 \\
\hline 2. & Pemenuhan terhadap standar & 9,00 & 15,00 & 8,00 \\
\hline 3. & Jumlah pembiayaan & 34,16 & 36,21 & 32,16 \\
\hline 4. & Kesesuaian proses pembiayaan dengan SOP & 9,00 & 9,00 & 9,00 \\
\hline 5. & $\begin{array}{l}\text { Jumlah laporan pembiayaan yang dibuat lengkap dan } \\
\text { tepat waktu }\end{array}$ & 10,00 & 14,00 & 9,00 \\
\hline \multicolumn{2}{|c|}{ Total } & $\mathbf{8 8 , 6 9}$ & $\mathbf{7 6 , 3 9}$ & $\mathbf{6 8 , 3 9}$ \\
\hline
\end{tabular}

Sumber: data internal PT. Adira Dinamika Multi Finance, Tbk Kantor Cabang Jayapura, 2020

Berdasarkan tabel di atas diketahui persentase penilaian kinerja manager pada PT. Adira Dinamika Multi Finance, Tbk Kantor Cabang Jayapura selama tahun 2017 sampai dengan tahun 2019. Hasil penilaian kinerja manajer fluktuatif pada beberapa indikator. Sementara pada nilai total mengalami trend penurunan. Persoalan kinerja manajerial yang paling disoroti adalah kekurang lengkapan dan keterlambatan penyampaian dokumen pertanggungjawaban. $\mathrm{Hal}$ - hal tersebut tentunya dapat menghambat kinerja manajerial PT. Adira Dinamika Multi Finance, Tbk Kantor Cabang Jayapura.

Berdasarkan uraian di atas, maka dilakukan penelitian dengan fokus "Pengaruh Sistem Akuntansi Manajemen Dan Ketidakpastian Lingkungan Terhadap Kinerja Manajerial Pada PT. Adira Dinamika Multi Finance, Tbk Kantor Cabang Jayapura."

\section{TINJAUAN PUSTAKA}

\subsection{Teori Penetapan Tujuan (Goal Setting Theory)}

Goal setting theory yang dikembangkan oleh Locke sejak 1968 telah mulai menarik minat dalam berbagai masalah dan isu organisasi. Menurut goal setting theory, individu memiliki beberapa tujuan, memilih tujuan, dan mereka termotivasi untuk mencapai tujuan-tujuan tersebut (Srimindarti, 2012). Teori ini mengasumsikan bahwa faktor utama yang memengaruhi pilihan yang dibuat individu adalah tujuan yang mereka miliki. Goal setting theory telah menunjukkan adanya pengaruh signifikan dalam perumusan tujuan (Arsanti, 2009). Kekhususan dan kesulitan merupakan atribut dari penetapan tujuan. Umumnya, semakin sulit dan spesifik tujuan yang ditetapkan, semakin tinggi tingkat prestasi yang akan dihasilkan.

Salah satu karakteristik dari goal setting adalah tingkat kesulitan tujuan. Tingkat kesulitan tujuan yang berbeda akan memberikan motivasi yang berbeda bagi individu untuk mencapai kinerja tertentu. Tingkat kesulitan tujuan yang rendah akan membuat individu memandang bahwa tujuan sebagai pencapaian rutin yang mudah dicapai sehingga akan menurunkan motivasi individu untuk berkreativitas dan mengembangkan kemampuannya. 
Sedangkan pada tingkat kesulitan tujuan yang lebih tinggi tetapi mungkin untuk dicapai, individu akan termotivasi untuk berfikir cara pencapaian tujuan tersebut. Proses ini akan menjadi sarana berkembangnya kreatifitas dan kemampuan individu untuk mencapai tujuan tersebut (Ginting dan Ariani dalam Matana, 2017).

Goal setting theory atau teori penetapan tujuan adalah proses kognitif membangun tujuan dan merupakan determinan perilaku. Prinsip dasar goal setting theory adalah goals dan intentions, yang keduanya merupakan penanggung jawab untuk human behavior. Dalam studi mengenai goal setting, goal menunjukkan pencapaian standar khusus dari suatu keahlian terhadap tugas dalam batasan waktu tertentu. Harder goal akan dapat tercapai bila ada usaha dan perhatian yang lebih besar dan membutuhkan lebih banyak knowledge dan skill daripada easy goal.

Mengacu pada Locke's model (Arsanti, 2009), goal setting theory atau teori penetapan tujuan mempunyai empat mekanisme dalam memotivasi individu untuk mencapai kinerja. Pertama, penetapan tujuan dapat mengarahkan perhatian individu untuk lebih fokus pada pencapaian tujuan tersebut. Kedua, tujuan dapat membantu mengatur usaha yang diberikan oleh individu untuk mencapai tujuan. Ketiga, adanya tujuan dapat meningkatkan ketekunan individu dalam mencapai tujuan tersebut. Keempat, tujuan membantu individu untuk menetapkan strategi dan melakukan tindakan sesuai yang direncanakan. Dengan demikian, dengan adanya penetapan tujuan dapat meningkatkan kinerja individu yang pada akhirnya akan meningkatkan kinerja perusahaan.
Komitmen harus ada dalam goal setting. Komitmen terhadap goal nampak secara langsung dan tidak langsung berpengaruh pada performance. Bila person's goal tinggi, maka high commitment akan membawa pada higher performance dibandingkan ketika low commitment. Tetapi, bila goals rendah, high commitment membatasi performance. Ginting dan Ariani dalam Matana (2017), menyatakan bahwa goal commitment berdampak pada proses goal setting yang akan berkurang bila ada goal conflict. Goal commitment berhubungan positif dengan goal directed behavior, dan goal directed behavior berhubungan positif dengan performance.

\subsection{Sistem Akuntansi Manajemen \\ a. Teori dan Definisi Akuntansi Manajemen}

Sistem informasi akuntansi manajemen adalah sistem informasi yang menghasilkan keluaran (output) dengan menggunakan masukan (input) dan memprosesnya untuk mencapai tujuan khusus manajemen. Hansen dan Mowen (2006) dalam Kumentas (2013), Sistem Akuntansi Manajemen mempunyai tiga tujuan yaitu menyediakan jasa informasi yang digunakan dalam perhitungan jasa, produk, dan tujuan lain yang diinginkan manajemen, untuk menyediakan informasi yang digunakan dalam perencanaan, pengendalian, dan pengevaluasian dan untuk menyediakan informasi yang berguna dalam pengambilan keputusan.

\section{b. Pengertian Sistem Akuntansi Manajemen}

Sistem akuntansi manajemen adalah salah satu bidang akuntansi yang tujuan utamanya untuk menyajikan informasi yang berguna dalam satuan usaha atau organisasi tertentu untuk kepentingan 
internal dalam rangka melaksanakan proses manajemen yang meliputi perencanaan, pembuatan keputusan, pengorganisasian, pengarahan dan pengendalian (Solechan, 2007 dalam Sianipar, 2018). Garrison dan Noreen (2000) dalam Sianipar (2018), menyatakan bahwa sistem akuntansi manajemen adalah akuntansi yang berkaitan dengan penyediaan informasi kepada para manajer untuk membuat perencanaan dan pengendalian operasi serta dalam pengambilan keputusan. Sistem akuntansi manajemen menggambarkan sebuah sistem yang didesain untuk menyediakan informasi untuk manajer. Sistem akuntansi manajemen merupakan bagian dari sistem pengendalian organisasi yang perludiperhatikan karena diharapkan dapat memberikan kontribusi yang positif didalam keberhasilan sistem pengendalian manajemen. Sistem akuntansi manajemen membantu manajer untuk mengendalikan aktivitas perusahaan sehingga dapat membantu perusahaan dalam mencapai tujuan perusahaan.

Astuti (2007) dalam Sianipar (2018), menyatakan bahwa sistem akuntansi manajemen adalah sistem informasi yang mengumpulkan data operasional dan finasial, memprosesnya, menyimpannya dan melaporkan kepada pengguna. Produk yang dihasilkan oleh sistem akuntansi manajemen adalah informasi akuntansi manajemen.

Prasetyo (2006) dalam Sianipar (2018), mengemukakan sistem akuntansi manajemen merupakan salah satu mekanisme pengendalian di dalam organisasi, serta alat yang efektif di dalam menyediakan informasi yang bermanfaat guna memprediksi konsekuensi yang mungkin terjadi dari berbagai aktivitas yang bisa dilakukan.Salah satu produk yang dihasilkan sistem akuntansi manajemen adalah informasi akuntansi manajemen yang berguna untuk membantu pekerja, manajer dan eksekutif untuk membuat keputusan yang lebih baik.

Sistem akuntansi manajemen dalam organisasi merupakan berperan membantu manajer atau orang-orang yang bertanggungjawab dalam pelaksanaan aktivitas-aktivitas perencanaan, pengorganisasian, pengarahan dan pengambilan keputusan. Sistem akuntansi manajemen merupakan sistem formal yang dirancang untuk menyediakan informasi untuk pengguna internal seperti manajer, eksekutif, dan para pekerja. Sistem akuntansi manajemen secara khusus akan menerapkan teknik-teknik dan konsep yang tepat dalam pengolahan data ekonomi historicaldan yang diproyeksikan dari satu satuan usaha untuk membantu manajemen dalam penyusunan rencana untuk tujuan-tujuan ekonomi yang rasional dan dalam membuat keputusan-keputusan rasional dengan satu pandangan kearah pencapai tujuan (Lempas \& Sabijono, 2014).

Sistem akuntansi manajemen yang merupakan bagian dari sistem pengendalian organisasi perlu mendapat perhatian, hingga dapat diharapkan akan memberikan kontribusi positif dalam mendukung keberhasilan sistem pengendalian manajemen (Lempas \& Sabijono, 2014). Sistem akuntansi manajemen yaitu suatu sistem pengolahan informasi keuangan yang digunakan untuk menghasilkan informasi keuangan bagi kepentingan pemakai intern organisasi (Mulyadi, 1997 dalam Setyolaksono, 2011). 


\section{c. Karakteristik Pengukuran Sistem Akuntansi Manajemen}

Chenhall dan Morris (1986) dalam Setyolaksono (2011), mengidentifikasi empat karakteristik informasi sistem akuntansi manajemen yaitu sebagai berikut:

\section{1) Broadscope}

Lingkup sistem akuntansi manajemen yang luas memberikan informasi yang berhubungan dengan lingkungan eksternal yang mungkin bersifat ekonomi seperti Gross National Product, total penjualan pasar dan pangsa pasar suatu industri, atau juga bersifat non ekonomi seperti faktor demografi, cita rasa konsumen, tindakan para pesaing dan perkembangan teknologi. Disamping itu, lingkup sistem akuntansi manajemen yang luas akan memberikan estimasi tentang kemungkinan terjadinya peristiwa di masa yang akan dating dalam ukuran probabilitas.

\section{2) Timeliness}

Informasi timeliness meningkatkan fasilitas sistem akuntansi manajemen untuk melaporkan peristiwa paling akhir dan untuk memberikan umpan balik secara tepat terhadap keputusan yang dibuat. Jadi timeliness mencakup frekuensi pelaporan dan kecepatan pelaporan.

\section{3) Aggregation}

Tipe aggregasi yang mangacu pada berbagai format yang konsisten dengan model keputusan formal seperti analisis cash flow yang didiskontokan untuk anggaran modal, simulasi dan linier programming untuk penerapan anggaran, analisis laba dan rugi dan analisis pengendalian intern.

\section{4) Integration}

Aspek pengendalian suatu organisasi yang penting adalah koordinasi berbagai segmen dalam sub-sub organisasi.
Karakteristik sistem akuntansi manajemen yang membantu koordinasi mencakup spesifikasi target yang menunjukkan pengaruh interaksi segmen dan informasi mengenai pengaruh keputusan pada operasi seluruh sub unit organisasi.

\subsection{Ketidakpastian Lingkungan}

Ketidakpastian merupakan suatu faktor dari situasi yang dihadapi oleh sebagian besar manajer pada organisasi yang sulit untuk diperkirakan. Susilo (2011), mendefinisikan ketidakpastian sebagai suatu keadaan dari ketidakcukupan informasi tentang pemahaman atau pengetahuan terkait dengan suatu peristiwa yang kemungkinan akan terjadi. Akibat yang ditimbulkan dari ketidakpastian tersebut adalah hasil dari keputusan yang telah dibuat mungkin akan berbeda dari apa yang telah diperkirakan sebelumnya saat pengambilan keputusan.

Setiap organisasi memiliki pandangan yang berbeda terhadap kondisi lingkungan yang dihadapinya. Hal ini dikarenakan, penilaian organisasi terhadap ketidakpastian yang dihadapi tergantung pada masing-masing persepsi manajemen serta kemampuannya dalam menilai dan memperkirakan situasi yang akan terjadi di masa yang akan datang. Semakin manajemen mampu memprediksi kondisi ketidakpastian di masa yang akan datang, maka semakin kecil persepsi manajemen mengenai ketidakpastian lingkungan. Menurut Daft (2010), ketidakpastian lingkungan adalah ketika seorang manajer tidak mempunyai informasi yang cukup mengenai faktorfaktor lingkungan untuk dapat memahami dan memperkirakan kebutuhan dan perubahan lingkungan. Selanjutnya ketidakpastian lingkungan menurut Akhmad dan Jauhar (2013) 
adalah suatu keadaan dimana organisasi atau pimpinannya tidak mempunyai informasi yang cukup mengenai keadaan lingkungannya, sehingga akan menyebabkan timbulnya kesulitan dalam memperkirakan perubahan-perubahan lingkungan yang akan terjadi.

Berdasarkan beberapa pengertian mengenai ketidakpastian lingkungan yang telah dikemukakan dapat disimpulkan bahwa ketidakpasitan lingkungan adalah rasa ketidakmampuan seseorang untuk memprediksi keadaan dimasa yang akan datang secara tepat dan akurat dari seluruh faktor yang secara langsung atau tidak langsung dapat mempengaruhi prilaku seseorang dalam pembuatan keputusan.

\subsection{Kinerja Manajerial}

Kinerja adalah hasil kerja secara kualitas dan kuantitas yang dicapai oleh seseorang dalam melaksanakan tugasnya sesuai dengan tanggung jawab yang diberikan kepadanya (Anwar Prabu Mangkunegara, 2004 dalam Sianipar, 2018). Wirawan (2009) dalam Sianipar (2018), menerangkan kinerja sebagai keluaran yang dihasilkan oleh fungsifungsi atau indikator-indikator suatu pekerjaan atau profesi dalam waktu tertentu. Menurut Wibowo (2010) kinerja adalah hasil pekerjaan.

Manajer adalah individu yang bertanggung jawab secara langsung untuk memastikan kegiatan dalam sebuah organisasi yang dijalankan bersama para anggota organisasi (Sule dan Saefullah, 2005 dalam Sianipar, 2018). Menurut Jeff Madura (2007) dalam Sianipar (2018), manajer adalah karyawan yang bertanggung jawab untuk mengatur pekerjaan karyawan lain (bawahannya) dan membuat keputusan bisnis penting. Jadi, manajer adalah individu yang mengatur karyawan, memastikan seluruh aktivitas dalam perusahaan dan membuat keputusan penting bagi perusahaan.

Menurut Mangkunegara (2005) dalam Sigillipu (2013), kinerja manajerial merupakan suatu proses kombinasi yang terus-menerus dilakukan dalam kerjasama antara seorang karyawan dan aturan langsung yang melibatkan penerapan pengharapan, serta pengertian tentang fungsi kerja karyawan. Kinerja manajerial yang diperoleh manajer juga merupakan salah satu faktor yang dapat dipakai untuk meningkatkan keefektifan perusahaan kinerja manajerial menurut Anwar dalam Marthin, dkk (2013), kinerja manajerial merupakan proses perencanaan, pengorganisasian, pelaksanaan, dan pengendalian terhadap pencapaian kinerja dan dikomunikasikan secara terus menerus oleh pimpinan kepada karyawan, antara karyawan dengan atasannya langsung. Sedangkan menurut Yuliana, dkk (2012), kinerja manajerial adalah kinerja para individu anggota sebuah organisasi dalam kegiatankegiatan manajerial.

Untuk dapat memperoleh kinerja manajerial yang maksimal diperlukan sistem pengendalian manajemen yang dapat dimanfaatkan untuk memotivasi seluruh personel perusahaan guna mewujudkan tujuan perusahaan melalui perilaku yang diharapkan. Sistem pengendalian manajemen ialah proses dan struktur yang tertata secara digunakan untuk mencapai tujuan perusahaan dengan strategi tertentu secara efisien. Unsur-unsur dari sistem pengendalian manajemen meliputi: perencanaan anggaran, alokasi sumber daya, pengukuran, evaluasi, penghargaan atas kinerja, pertanggungjawaban, dan 
penetapan harga transfer (Sulijaya \& Nuraini, 2015).

Menurut Narsa dan Yuniawati (2003) dalam Adang \& Hernawati (2013), menyatakan bahwa Kinerja Manajerial adalah kinerja para individu dalam kegiatan manajerial. Kinerja personel melputi 8 dimensi yaitu:

1) Perencanaan, perencanaan dalam arti kemampuan untuk menentukan tujuan, kebijakan dan tindakan/pelaksanaan, penjadwalan kerja, penganggaran, merancang prosedur, dan pemrograman.

2) Investigasi yaitu kemampuan mengumpulkan dan menyampaikan informasi untuk catatan, laporan, dan rekening, mengukur hasil, menentukan persediaan, dan analisis pekerjaan.

3) Pengkoordinasian yaitu kemampuan melakukan tukar menukar informasi dengan orang lain di bagian organisasi yang lain untuk mengkaitkan dan menyesuaikan program, memberitahu bagian lain, dan hubungan dengan manajer lain.

4) Evaluasi yaitu kemampuan untuk menilai dan mengukur proposal, kinerja yang diamati atau dilaporkan, penilaian pegawai, penilaian catatan hasil, penilaian laporan keuangan, pemeriksaan produk.

5) Pengawasan (supervisi) yaitu kemampuan untuk mengarahkan, memimpin dan mengembangkan bawahan, membimbing, melatih dan menjelaskan peraturan kerja pada bawahan, memberikan tugas pekerjaan dan menangani bawahan.

6) Pengaturan staff (staffing) yaitu kemampuan untuk mempertahankan angkatan kerja dibagian anda, merekrut, mewawancarai dan memilih pegawai baru, menempatkan, mempromosikan dan mutasi pegawai.

7) Negosiasi yaitu kemampuan dalam melakukan pembelian, penjualan atau melakukan kontrak untuk barang dan jasa, menghubungi pemasok, tawar menawar dengan wakil penjual, tawar-menawar secara kelompok.

8) Perwakilan (representatif) yaitu kemampuan dalam menghadiri pertemuanpertemuan dengan perusahaan lain, pertemuan perkumpulan bisnis, pidato untuk acara-acara kemasyarakatan, pendekatan kemasyarakatan, mempromosikan tujuan umum perusahaan. Tujuan utama penilaian kinerja dalah untuk memotivasi personil dalam mencapai sasaran organisasi dan dalam memahami standard.

Menurut Wibowo (2010), manajemen kinerja adalah manajemen tentang menciptakan hubungan dan memastikan komunikasi yang efektif. Manajemen kinerja memfokuskan pada apa yang diperlukan oleh organisasi, manajer dan pekerja untuk berhasil. Dapat ditarik kesimpulan Kinerja Manajerial adalah tentang bagaimana kinerja dikelola untuk memperoleh sukses. Kinerja berasal dari pengertian performance. Kinerja merupakan hasil pekerjaan yang mempunyai hubungan kuat dengan tujuan strategis organisasi, kepuasan konsumen dan memberikan kontribusi pada ekonomi. Dengan demikian, kinerja adalah tentang melakukan pekerjaan dan hasil yang dicapai dari pekerjaan tersebut. Kinerja adalah tentang apa yang dikerjakan dan bagaimana cara mengerjakannya. 


\section{METODE PENELITIAN}

\subsection{Metode Analisis Data}

\section{a. Analisis Deskriptif}

Analisis deskriptif adalah suatu metode analisis dimana data-data dikumpulkan, diklarifikasikan, dikelompokkan, selanjutnya dianalisis dan diinterpretasikan secara objektif dalam rangka menerangkan objek tertentu. Penelitian ini menggunakan analisis deskriptif untuk membantu menerangkan hasil temuan penelitian.

\section{b. Uji Instrumen Penelitian}

\section{1) Uji Validitas}

Validitas adalah skala dimana kesimpulan yang dibuat dengan berdasarkan skor menurut angka menjadi sesuai. Pengujian validitas ini menggunakan Total Correlation (Corrected Item), analisis ini dengan caramengkolerasikan masing-masing skor item dengan skor total dan melakukan koreksi terhadap nilai koefisien korelasi yang overestimasi. Pengujian menggunakan dua sisi dengan taraf signifikasi 0,05.

\section{2) Uji Reliabilitas}

Pengujian ini menggunakan metode statistik Cronbach Alpha dengan nilai sebesar 0,06. Apabila Cronbach Alpha dari suatu variabel $\geq 0,6$ maka butir pertanyaan dalam instrumen penelitian tersebut adalah reliabel atau dapat diandalkan, dan sebaliknya jika nilai Cronbach Alpha $<0<6$ maka butir pertanyaan tersebut tidak reliabel.

\section{b. Uji Asumsi Klasik}

Uji asumsi klasik digunakan untuk mengetahui apakah hasil analisis regresi linier berganda yang digunakan untuk menganalisis dalam penelitian ini terbebas dari penyimpangan asumsi klasik. Uji asumsi klasik yang digunakan dalam penelitian ini meliputi uji normalitas, multikolinieritas, dan heteroskedastisitas. Adapun masingmasing pengujian tersebut dapat dijabarkan secara ringkas sebagai berikut:

\section{1) Uji Normalitas}

Uji normalitas bertujuan untuk menguji apakah dalam suatu model regresi linier variabel terikat dan variabel bebas keduanya mempunyai distribusi normal atau tidak (Ghozali, 2015). Setiap penelitian mengharuskan normalitas data dengan kata lain model regresi yang baik tercermin dari distribusi data normal.

\section{2) Uji Multikolinearitas}

Uji multikolinieritas bertujuan untuk menguji apakah model regresi mempunyai korelasi antara variabel bebas, dengan kata lainModel regresi yang baik seharusnya tidak terjadi korelasi diantara variabel independen. Dalam hal ini disebut variabel-variabel bebas ini tidak ortogonal.

Dalam mendeteksi ada tidaknya multikolinearitas di dalam model regresi salah satunya dilihat dari: (1) nilai tolerance dan lawannya; dan (2) variance inflation factor (VIF). Kedua ukuran ini menunjukan setiap variabel independen manakah yang dijelaskan oleh variabel independen lainnya. Nilai cut off yang umum dipakai untuk menunjukan adanya multikolinearitas adalah nilai tolerance < 0.10 atau sama dengan nilai VIF $>10$ (Ghozali, 2015).

\section{3) Uji Heteroskedastisitas}

Uji heteroskedastisitas bertujuan menguji model regresi, apakah terdapat ketidaksamaan variance dari residual satu pengamatan ke pengamatan lain. Konsekuensinya adanya heteroskedastisitas dalam model regresi adalah penaksir yang diperoleh tidak efisien, baik dalam sampel kecil maupun 
besar. Salah satu cara yang dapat digunakan untuk mengetahui ada tidaknya gejala heteroskedastisitas adalah dengan melihat pada grafik scatter plot. Jika ada pola tertentu seperti titiktitik yang membentuk pola tertentu yang teratur (bergelombang, melebar, kemudian menyempit) maka mengindikasikan telah terjadi heteroskedastisitas. Jika tak ada pola yang jelas maka tidak terjadi gejala heteroskedastisitas.

\section{c. Uji Hipotesis}

\section{1) Analisis Regresi Linear Berganda}

Analisis regresi linear berganda digunakan untuk mengetahui pengaruh antara variabel bebas terhadap variabel terikat. Persamaan regresi linear berganda yaitu:

$\mathrm{Y}=\boldsymbol{\beta}_{0}+\beta 1 \mathrm{X} 1+\beta 2 \mathrm{X} 2+\mathrm{e}$

Keterangan:

$\begin{array}{ll}\mathrm{Y} & =\text { Kinerja Manajerial } \\ \beta_{0} & =\text { Nilai Konstan } \\ \mathrm{X} 1 & =\text { Sistem Akuntansi } \\ & \\ \mathrm{X} 2 & =\text { Manajemen } \\ \beta_{1}, \beta_{2} & =\text { Ketidakpastian Lingkungan } \\ \mathrm{e} & =\text { Standar error }\end{array}$

\section{2) Uji parsial (uji t)}

Penelitian ini menggunakan uji thitung bertujuan untuk melihat secara parsial apakah ada pengaruh dari variabel bebas terhadap variabel terikat. Penelitian ini akan menggunakan uji $\mathrm{t}$ untuk menguji hipotesis $\mathrm{H} 0$ atau hipotesis $\mathrm{H} 1$ yang telah diajukan dengan melihat signifikansi pada masing-masing thitung. Jika nilai signifikan lebih kecil dari 0,05 atau 5\% maka hipotesis yang diajukan diterima atau dikatakan signifikan, sedangkan jika nilai signifikan lebih besar dari 0,05 atau 5\% maka hipotesis yang diajukan ditolak atau dikatakan tidak signifikan.

\section{3) Pengujian Koefisien Determinan $\left(\mathbf{R}^{2}\right)$}

Uji Determinan membantu melihat seberapa besar kontribusi variabel bebas terhadap variabel terikat. Dengan kata lain koefisien determinan digunakan untuk mengukur besarnya pengaruh variabel bebas yang diteliti terhadap variabel terikat. Koefisien determinan $\left(\mathrm{R}^{2}\right)$ berkisar antara nol sampai dengan satu $\left(0 \leq R^{2} \leq 1\right)$. Hal ini berarti $R^{2}=0$ menunjukkan tidak adanya pengaruh variabel bebas terhadap variabel terikat.

\section{HASIL DAN PEMBAHASAN}

\subsection{Pengaruh Sistem Akuntansi Manajemen terhadap Kinerja Manajerial}

Sistem akuntansi manajemen merupakan instrumen yang digunakan untuk mengukur tingkat keandalan informasi akuntansi manajemen. Instrumen yang digunakan untuk mengukur tingkat keandalan informasi akuntansi manajemen dibagi menjadi empat. Keempat indikator diadopsi dari peneliti terdahulu (Sianipar, 2018). Variabel Sistem Akuntansi Manajemen dalam penelitian ini diukur dengan empat indicator yakni broadscope, timelines, aggregation dan integration.

Berdasarkan hasil penelitian diketahui bahwa sistem akuntansi manajemen memiliki pengaruh positif terhadap kinerja manajerial. Hal ini berarti bahwa penerapan sistem akuntansi manajemen memiliki pengaruh searah terhadap kinerja manajerial. Peningkatan sistem akuntansi manajemen akan memberikan dampak pada meningkatnya kinerja manajerial. Dengan kata lain, jika PT. Adira Dinamika Multi Finance, Tbk Kantor Cabang Jayapura, selalu menyediakan, memproses dan mendistribusikan 
informasi akuntansi pada setiap bagian/devisi dalam perusahaan maka akan memberikan dampak pada peningkatan kinerja manajerial.

Berdasarkan uji parsial diketahui bahwa sistem akuntansi manajemen memiliki pengaruh yang signifikan terhadap kinerja manajerial. Hal ini berarti bahwa sistem akuntansi manajemen merupakan faktor penentu baik dan tidaknya kinerja manajerial pada PT. Adira Dinamika Multi Finance, Tbk Kantor Cabang Jayapura. Hasil penelitian ini sejalan dengan teori yang dikemukakan Mia dan Chanel dalam Sianipar (2018), bahwa jika para manajer menggunakan informasi yang disediakan oleh sistem akuntansi manajemen maka para manajer tersebut dapat melaksanakan hal yang lebih baik dalam melaksanakan pekerjaan dan perbaikan dalam kinerjanya.

Sementara itu, berdasarkan temuan penelitian menunjukkan bahwa persepsi para menejer baik tentang penerapan Sistem Akuntansi Manajemen di PT. Adira Dinamika Multi Finance, Tbk Kantor Cabang Jayapura. Para manajer mendukung ada ketersediaan informasi akuntansi tentang perkembangan perusahaan yang selalu tersedia. Para manajer juga bersepakat bahwa hasil informasi akuntansi disalurkan kepada masing - masing bagian guna masing masing bagian dapat memahami dampak dalam setuap keputusan akuntansi.

Hasil penelitian ini sejalan dengan hasil penelitian sebelumnya dari Sulani (2013), Wulandari, dkk (2014), Lempas,dkk (2014), Rante, dkk (2014), Lempas (2014), Eliana, dkk (2014), Pratami (2015), Syafira (2015), Damayanti, dkk (2015), Solikah (2017), dan Qibtiyah (2018) yang menemukan bahwa sistem akuntansi manajemen berpengaruh positif dan signifikan terhadap kinerja manajerial.

\subsection{Pengaruh \\ Ketidakpastian Lingkungan terhadap Kinerja Manajerial}

Ketidakpastian lingkungan adalah situasi di mana seseorang terkendala untuk memprediksi keadaan sekitar sehingga sulit untuk mengetahui gagal atau berhasilnya keputusan yang dibuat. Ketidakpastian lingkungan yang dihadapi perusahaan merupakan salah satu faktor yang mempengaruhi kemampuan manajer dalam memprediksi situasi yang akan terjadi dimasa yang akan datang. Variabel ketidakpastian lingkungan dalam penelitian ini diukur dengan sepuluh indicator yakni metode penyusnan anggaran, penyediaan informasi, pengukuran keputusan, keputusan, tindakan penyesuaian, tindakan dengan sasaran, bekerja sesuai informasi, kesulitan dan pekerjaan yang harus dilakukan.

Berdasarkan hasil penelitian diketahui bahwa ketidakpastian lingkungan memilki pengaruh positif terhadap kinerja manajerial. Hal ini berarti bahwa ketidakpastian lingkungan merupakan faktor pendukung kinerja manajerial. Sebagaimana hasil penelitian Sulkiah (2016), bahwa ketidakpastian lingkungan dapat membuat manajer bersiap diri untuk meningkatkan kinerja dengan cara memperoleh informasi agar mampu menghadapi ketidakpastian lingkungan yang terjadi sehingga dengan adanya informasi juga akan meningkatkan kemampuan manajemen untuk memahami keadaan lingkungan sebenarnya dan informasi berfungsi pula mengidentifikasikan aktivitas yang relevan.

Berdasarkan hasil uji parsial diketahui bahwa ketidakpastian memiliki 
pengaruh signifikan terhadap kinerja manajerial. Hal ini berarti bahwa ketidakpastian lingkungan merupakan faktor penentu baik dan tidaknya kinerja manajerial. Hal ini menunjukkan bahwa dengan adanya ketidakpastian lingkungan, para manajer PT. Adira Dinamika Multi Finance, Tbk Kantor Cabang Jayapura akan berusaha mencari informasi yang berguna sebagai bahan menyusun perencaan dan kontrol bagi perusahaan.

Sementara itu, berdasarkan hasil persepsi para menajer yang menjadi responden dalam penelitian ini menunjukkan bahwa para manajer paham tentang metode penyusunan anggaran, menyediakan informasi penting dan melakukan penyesuaian penyesuaian. Para menajer di PT. Adira Dinamika Multi Finance, Tbk Kantor Cabang Jayapura, juga memahami bahwa keputusan - keputusan yang dibuat harus sesuai dengan sasaran anggaran.

Hasil penelitian ini sejalan dengan hasil penelitian sebelumnya dari Damayanti (2015) dan Prihatningtyas (2018), yang menemukan bahwa ketidakpasitan lingkungan berpangaruh terhadap kinerja manajerial.

\section{PENUTUP}

\subsection{Simpulan}

Berdasarkan hasil penelitian dan pembahasan maka simpulan dari penelitian ini adalah sebagai berikut:

1. Sistem Akuntansi Manajemen berpengaruh positif dan signifikan terhadap kinerja manajerial pada PT. Adira Dinamika Multi Finance, Tbk Kantor Cabang Jayapura. Hal ini berarti sistem akuntansi manajemen merupakan faktor pendukung dan penentu baik dan tidaknya kinerja manajer.
2. Ketidakpastian lingkungan berpengaruh positif dan signifikan terhadap kinerja manajerial pada PT. Adira Dinamika Multi Finance, Tbk Kantor Cabang Jayapura. Hal ini berarti ketidakpastian lingkungan merupakan faktor pendukung dan penentu baik dan tidaknya kinerja manajer.

\subsection{Saran}

Berdasarkan simpulan penelitian di atas maka saran yang diajukan dari penelitian ini adalah sebagai berikut:

1. Kepada PT. Adira Dinamika Multi Finance, Tbk Kantor Cabang Jayapura diharapkan untuk dapat mempertahankan penerapan sistem akuntansi manajemen dan partisipasi anggarannya karena telah terbukti mampu untuk meningkatkan kinerja pejabat strukturalnya.

2. Kepada peneliti selanjutnya agar menambah atau mengganti variable lainnya yang berhubungan dengan kinerja manjerial seperti sikap atasan, budaya organisasi dan aspek religiusitas. Selain itu agar dapat melakukan penelitian sejenis pada perusahaan yang berbeda sehingga hasil penelitian bisa digeneralisir.

\section{DAFTAR PUSTAKA}

Adang, Y. S. P. dan Hernawati, E. 2013. Pengaruh Sistem Pengukuran Kinerja Total Quality Management dan Sistem Penghargaan terhadap Kinerja Manajerial. Jurnal Universitas Pembangunan Nasional Veteran Jakarta.

Akhmad, Subkhi dan Moh. Jauhar. 2013. Pengantar Teori dan Perilaku Organisasi. Jakarta: Prestasi Pustaka.

Anita, Lella. 2017. Pengaruh Ketidakpastian Lingkungan 
Terhadap Kinerja Manajerial Dengan Sistem Informasi Akuntansi Manajemen Sebagai Variabel Pemediasi. Tesis. Universitas Lampung.

Arsanti, Tutuk. 2009. Hubungan antara Penetapan Tujuan, Self Efficacy dan Kinerja. Jurnal Bisnis dan Ekonomi. Vol. 16, No. 2, ISSN: 1412-3126.

Ayu, Gusti, dan Lovelly Dwinda Dahen. 2014. Pengaruh Karakteristik Informasi Sistem Akuntansi Manajemen terhadap Kinerja Manajerial Studi Empiris pada PT Bank Perkreditan Rakyat di Kabupaten Tanah Datar. ISSN: 2302-1590. E-ISSN: 2460-1900. Journal of Economic and Economic Education. Volume 3. Nomor 1, 9499.

Daft, Richard L. 2010. Era Baru Manajemen Edisi Kesembilan, buku 2. Jakarta: Salemba Empat.

Damayanti, P. E., Sujana, E., \& Werastuti, D. N. S. 2015. Pengaruh Karakteristik Informasi Sistem Akuntansi Manajemen (SAM), Desentralisasi, dan Ketidakpastian Lingkungan Terhadap Kinerja Manajerial (Studi Empiris Pada Hotel Se-Kabupaten Buleleng). EJournal S1 AK UPG, 3 No. 1.

Devianti, Heny. 2017. Pengaruh Partisipasi Anggaran Terhadap Kinerja Manajerial Dengan Kepuasan Kerja Sebagai Variabel Intervening. Thesis, Universitas Lampung.

Eliana, Muhammad Arfan, dan Hasan Basri. 2014. Pengaruh Sistem Akuntansi Manajemen Dan Audit Internal Terhadap Kinerja Manajerial (Studi Pada Lembaga Keuangan Mikro Di Banda Aceh). Jurnal Magister Akuntansi. Pascasarjana Universitas Syiah Kuala. Volume 3, No. 3, Agustus 2014
Ingkiriwang, Octavia Ferona. 2013. Pengaruh Desentralisasi dan Sistem Akuntansi Manajemen Terhadap Kinerja Manajerial Dealer Di Manado. ISSN: 2303-1174. Jurnal EMBA. Vol.1 No.3. Hal 818-825.

Kumentas, Cynthia N. 2013. Pengaruh TQM, Sistem Pengukuran Kinerja, dan Penghargaan Terhadap Kinerja Manajerial Pada PT. Pos Indonesia. Jurnal EMBA. Vol. 1,(3), hlm 796805.

Lempas, Yuwinda. 2014. Desentralisasi Dan Sistem Akuntansi Manajemen Terhadap Kinerja Manajer Pada PT. Sinar Galesong Prima Manado. Jurnal EMBA. Vol.2 No.1 Maret 2014, Hal. 431 - 440.

Marthin, Titien., David P.E Saerang, Sifrid S. Pangemanan. 2013. Pengaruh Partisipasi Penyusunan Anggaran, Motivasi dan Pelimpahan Wewenang Terhadap Kinerja Manajerial Dinas Daerah Kabupaten kepulauan Siau Tagulandang Biaro. Jurnal Riset Akuntansi Going Concern, Vol. 8 No. 3, hlm 13-25.

Matana, Anastasia, 2017. Pengaruh Total Quality Management Terhadap Ekspektasi Kinerja Karyawan Pada PT. Pelabuhan Indonesia IV (Persero). Fakultas Ekonomi dan Bisnis, Universitas Hasanuddin, Makasar.

Pratami, Indri Paundria Nagari. 2015. Pengaruh Sistem Informasi Akuntansi Manajemen Dan Budaya Organisasi Terhadap Kinerja Manajerial (Studi pada PT. Pos Indonesia (Persero) Kota Bandung Jawa

Barat). http://repository.unpas.ac.i d/5644/ diakses pada 5 Agustus 2019.

Prihatningtyas, Canggih Nur. 2018. Pengaruh Ketidakpastian Lingkungan, Desentralisasi, Dan Sistem Akuntansi Manajemen Terhadap Kinerja Manajerial. Jurnal 
Akuntansi dan Sistem Teknologi Informasi Vol. 14 Edisi Khusus April 2018: 169 - 179

Qibtiyah, Mariyatul. 2018. Pengaruh Desentralisasi Dan Sistem Akuntansi Manajemen Terhadap Kinerja Manajerial Pada Politeknik Kesehatan Siteba. https://osf.io/xut37/ diakses pada 5 Agustus 2019.

Rante, Andika., Rosidi Rosidi dan Ali Djamhuri. 2014. Sistem Akuntansi Manajemen, Gaya Kepemimpinan, Dan Desentralisasi Sebagai Determinan Kinerja Manajerial. Jurnal Akuntansi Multiparadigma. https://jamal.ub.ac.id/index.php/i amal/article/view/287 diakses pada 5 Agustus 2019.

Setyolaksono, Bhakti. 2011. Pengaruh Desentralisasi dan Sistem Akuntansi Manajemen terhadap Kinerja Manajerial, Kasus pada Industri Es Balok di Kota Semarang. Skripsi Universitas Negeri Semarang: Semarang.

Sianipar, Mawar Sari. 2018. Pengaruh Sistem Akuntansi Manajemen, Sistem Pengendalian Manajemen, Motivasi Dan Komitmen Organisasi Terhadap Kinerja Manajerial (Studi Empiris Pada PT. PLN Area Pekanbaru).Skripsi thesis, Universitas Islam Negeri Sultan Syarif Kasim Riau.

Sigillipu, Steffi. 2013. Pengaruh Penerapan Informasi Akuntansi Manajemen dan Sistem Pengukuran Kinerja Terhadap Kinerja Manajerial. ISSN: 2303- 1174. Jurnal EMBA. Vol. 1No.3 Juni 2013. Hal 239-247.

Solikah, Duwi. 2017. Pengaruh Karakteristik Broad Scope Sistem Akuntansi Manajemen Terhadap Kinerja Manajerial Dengan Ketidakpastian Lingkungan Dan Desentralisasi Sebagai Variabel Moderating (Studi Empiris Pada
Bank Yang Ada Di

Ponorogo). Skripsi. Universitas Muhammadiyah Ponorogo.

Srimindarti, Ceacilia. 2012. Faktor-faktor yang Mempengaruhi Premature SignOff dengan Turnover Intention sebagai Variabel Intervening: Suatu Tinjauan dari Goal Setting Theory. Jurnal Organisasi dan Manajemen. Vol. 8, No. 2, Hal. 102-110.

Sulani, Sri. 2013. Pengaruh Karakteristik Sistem Akuntansi Manajemen Terhadap Kinerja Manajerial (Studi Kasus BPR Di Kabupaten Demak). Jurnal Akuntansi Indonesia, Vol. 3 No. 2 Juli 2013, Hal. 97 - 111.

Sulkiah. 2016.Pengaruh Ketidakpastian Lingkungan dan Lingkungan Sistem Akuntansi Manajemen Terhadap Kinerja Manajerial (Studi Empiris: Rumah Sakit Di Lombok Timur). Jurnal Ilmiah Rinjani Universitas Gunung Rinjani Vol. 4 Tahun 2016.

Sulijaya, Feliana \&Nuraini Bangun. 2015. Pengaruh TQM, Motivasi Dan Komitmen Organisasi Terhadap Kinerja Manajerial. Jurnal Akuntansi Vol. XIX No. 03 September 2015, hlm 433-448.

Susilo, L. J. dan Kaho, V. R. 2011. Manajemen Risiko Berbasis ISO 31000: Untuk Industri nonperbankan.

Syafira, Amalia. 2015. Pengaruh Sistem Akuntansi Manajemen (SAM) terhadap Kinerja Manajerial dengan Sistem Pengukuran Kinerja dan Sistem Reward sebagai Variabel Moderating (Studi Empiris pada Perusahaan BUMN Kota Padang). http://ejurnal.bunghatta.ac.id/ind ex.php?journal=JFEK\&page=article \&op=view\&path $\% 5 B \% 5 \mathrm{D}=4748$ diakses pada 5 Agustus 2019.

Wibowo. 2010. Manajemen Kinerja. Jakarta: PT. Raja Grafindo Persada.

Wulandari, N., \& Santoso, S. 2013. Pengaruh Sistem Akuntansi 
Manajemen, dan Desentralisasi Terhadap Kinerja Manajerial Pada Pegawai Kantor Pemerintah DaerahKabupaten Ngawi. Jurnal Akuntansi.

Yuliana., Nadirsyah dan Umar Bakar. 2012. Pengaruh Penerapan Total Quality Management Terhadap Kinerja Manajerial Dengan Budaya Organisasi, Sistem Pengukuran Kinerja dan Sistem Penghargaan Sebagai Variabel Moderating (Studi Empiris Pada Manajer Bank-Bank Yang Beroperasional Di Banda Aceh). Jurnal Akuntansi. Volume 2, No. 1, November 2012. Hal. 127141. 